\title{
THE 1967 PATENT LAW DEBATE- FIRST-TO-INVENT VS. FIRST-TO-FILE
}

\author{
Grorge E. Frost*
}

United States patent law has traditionally been based on the proposition that the first inventor, not the first person to file a patent application, is the only person entitled to a patent. Nevertheless, the President's Commission on the Patent System has proposed that patent rights be awarded on a first-to-file basis, and this recommendation is now embodied in bills before Congress. The author urges that the conclusion that a pure first-to-file system would be better for the United States should not be too hastily drawn. He reveals that the present United States patent system is neither purely a first-to-invent nor first-to-file system, but a hybrid system containing many features of both that gives a great advantage to the first person to file a patent application while also retaining important aspects of a first-to-invent system.

TN LATE 1966, the President's Commission on the Patent System 1 recommended a number of changes in the United States patent law. ${ }^{1}$ Principal among these was the proposal that patent rights be awarded to the first person to file a patent application. This is the practice in almost all foreign countries. In contrast, current United States law is based on the proposition that the first inventor, not the first to file a patent application, is the only person entitled to a patent. The proposal of the President's Commission is embodied in bills now before the Congress, ${ }^{2}$ which were introduced at the request of the President and have Administration support. ${ }^{3}$

\section{The Two Basic Patent Systems-First-to-Invent and FIRST-TO-FILE}

All important patent systems have been based on the filing of an application for patent by the inventor or his assignee. Such application must be in proper form and accompanied by the prescribed fee.

\footnotetext{
* B.S. 1940, Illinois Institute of Technology; J.D. 1945, George Washington University. Director, Patent Section, General Motors Corporation.

1 President's Commission on the Patent System, To Promote the Progress of UseFUL ARTS (1966).

=S. 1691, 90th Cong., 1st Sess. (1967); H.R. 5924, 90th Cong., 1st Sess. (1967).

H.R. Doc. No. 59, 90th Cong., lst Sess. iii to v (1967).
} 
In some countries, such as France, a registration procedure is followed: the applications are given a clerical review and then issued as patent grants. In the examining countries, such as the United States, Canada, Great Britain, West Germany, and Japan, the applications are given some form of initial clerical review, a filing date is assigned, and they are then put in line for examination. The examination process usually requires one to three or more years. In each system there is the possibility of two or more patent applications for the same invention-a possibility that occurs with sufficient frequency to be important. In addition, there is the chance of a patent application to subject matter which, at the time of the application, was known to persons other than the patent applicant. Both situations give rise to basic problems of patent administrationdetermining, as between two or more rival claimants, who is entitled to the patent and determining in infringement proceedings the extent that knowledge of the invention by others before the patent application in question was filed should be a defense.

Under the United States patent law, the defendant in an infringement suit has always been allowed to show that the patentee was not the first inventor. However, the historical antecedents of the law, as well as the 1790 United States Patent Act itself, ${ }^{4}$ developed without any apparent consideration of the problem of resolving conflicts between rival applicants. It remained for controversies that arose in the administration of the 1790 Act to point clearly to the need for some mechanism for handling this situation in the patent application stage. ${ }^{5}$ The Patent Office interference practice, first specifically delineated in the Patent Act of $1836,{ }^{6}$ was devised to resolve this problem. This practice, and the defense of prior invention in patent infringement suits which generated it, remains a distinctive aspect

- Act of April 10, 1790, ch. 7, 1 Stat. 109.

- For the history of the Act see Proceedings in Congress During the Years 1789 and 1790, Relating to the First Patent and Copyright Laws, 22 J. Pat. OfF. Soc'y 243.88, 352-71 (1940). Section 5 of the 1790 Act provided for repeal of an issued patent upon a showing that the "patentee was not the first and true inventor or discoverer." Section 6 of the Act provided that a defendant in an infringement suit could show that the patentee was not the first and true inventor or discoverer. The 1790 Act also provided in $\$ 1$ for a Patents Board, consisting of the Attorney General and the Secretaries of State and War, to determine whether applications for patent should be granted. The Board encountered a number of conflicting applications and is said to have made determinations of which of the conflicting applications should issue. Federico, Operation of the Patent Act of 1790, 18 J. PAT, OFF. Soc'y 237 (1936).

- Act of July 4, 1836, ch. 357, $\S 8,5$ Stat. 120. 
of United States patent law. Similar requirements, however, are imposed by the Philippines and Canada. ${ }^{7}$

The basic principle of Patent Office interference practice is that the patent should go to the first inventor. This in turn derives from the principle that the defendant in an infringement suit can show that one other than the patentee is the first inventor, and thereby secure a judgment of patent invalidity. As discussed hereafter, the concept of "first inventor" is rather esoteric-some things that logically might make one a first inventor are irrelevant and other things that would seem logically unimportant are critical. But, apart from the perplexities of the doctrine in detail, the grand design of the United States patent law is to ( 1 ) resolve conflicting patent applications by determining who is the first inventor and (2) permit an infringement suit defendant to show that one other than the patentee is the first inventor.

Another way to determine which of two rival inventors is entitled to a patent is by recourse to the patent application filing date. In the most strict form of this system, the patent application filing date is the sole determining factor. Actual acts of invention by the patentee, or by others, are totally irrelevant. This system, usually with some exceptions to the strict form, is utilized in all patent system countries other than the United States, Canada, and the Philippines. As a corollary to this mode of granting patents, the first-to-file systems do not have the infringement suit defense that the patentee is not the first inventor.

\section{A Comparative Analysis of the First-to-Invent and First-to-File Patent Systems}

There are numerous practical pros and cons of first-to-invent and first-to-file patent systems. The predominant advantage of a first-tofile system is the availability and decisiveness of the filing date. The date is a matter of record, readily established, and almost never sub-

7 Philippine patent statutes provide for the defense of prior invention in patent infringement suits. Law of June 20, 1947, Concerning the Issuance of Patents, [1947] Laws and Resolutions of the Republic of the Philippines 153. Canadian patent law also provides a defense of prior invention in infringement actions, but in Canada the first person to conceive of the invention is deemed by the courts to be the "first inventor.". See Christiani v. Rice, [1930] Can. S. Ct. 443, 456. The Canadian conflict procedure is defined in Canadian Patent Office Rules 66-74. Decisions with regard to priority are made upon the basis of affidavits that set forth disclosure of the invention, drawings, and so forth. 
ject to controversy. The person entitled to the patent is thus readily determined, the whole question of right to a patent vis-d-vis other inventors is quickly and easily ascertained, and no legal controversy in patent application or in infringement proceedings is likely. In addition, the first applicant to file has some claim of merit because he has started formal steps to make the invention public.

The most basic advantage of a first-to-invent system is that it awards patent rights to the person who best qualifies as first to create the invention. As developed later in this paper, the "first inventor" concept, as it has evolved in the United States, now means the first person to perfect the invention to a point of demonstrable practicality. A "reduction to practice," actual or constructive, is required. Agility and speed in preparing and filing a patent application are not essential. Ability, initiative, and success in conceiving and practically demonstrating the invention are sufficient.

It should be added that in Canada, the only other country that has any form of significantly developed first-to-invent system, the first "inventor" is really the first person to "conceive" or think of the invention. 8 The Canadian system can be supported on the ground that it, too, awards the patent upon the basis of what is done rather than speed in rushing into the Patent Office. The argument is considerably weaker, however, than that applicable under the United States reduction to practice test.

A number of additional considerations must be taken into account in making a comparative evaluation of first-to-invent and first-to-file patent systems. One is the "grace period" as to prior art. Every patent system must rest upon a defined body of knowledge with respect to which the presence or absence of an inventive contribution is to be tested. This is the "prior art." Section 103 of the 1952 Patent Act, ${ }^{\circ}$ for example, demands that the patented subject matter be unobvious in relation to the "prior art,"10 while section 102 of the Act defines the components of the "prior art."11 In the United States system, the "prior art" consists of patents and publications in

\footnotetext{
${ }^{8}$ See note 7 supra.

- Section 103 of the Act provides that "A patent may not be obtained though the invention is not identically disclosed ... if the differences between the subject matter sought to be patented and the prior art are such that the subject matter as a whole would have been obvious ...." 35 U.S.C. $\$ 103$ (1964).

${ }^{10}$ United States v. Adams, 383 U.S. 39 (1966); Graham v. John Deere Co., 383 U.S. 1 (1966).

${ }^{11}$ See 35 U.S.C. § 102 (1964).
} 
any country either ( 1 ) before the invention date or (2) more than one year before the patent application filing date. Patent applications filed in the United States prior to the invention date of an applicant are also prior art." In addition, creations "known or used" (that is, invented) by another in this country before the invention date, or in "public use or on sale in this country" more than one year before the patent application filing date are part of the prior art. ${ }^{13}$ The patent systems of other countries incorporate somewhat similar definitions of the prior art, with one exception. In most countries, there is no general one year "grace period" allowance between the date of prior art (e.g., a printed publication) and the patent application filing date. ${ }^{14}$

The first-to-invent system lends itself to provision of a "grace period," although it is workable without such a period. 15 The "grace period" is an important aspect of the United States patent law. The United States law is comparatively strict as to what constitutes a printed publication and what constitutes a public use. ${ }^{16}$ In addition, the United States patent law, as it has developed, imposes require-

1235 U.S.C. $\$ 102$ (e) (1964), construed in Hazeltine Research, Inc. v. Brenner, 382 U.S. 252 (1965).

${ }^{28} 35$ U.S.C. $\$ 102$ (a) and (b). See generally Note, Prior Art in the Patent Law, 79 HARY. L. REv. 369 (1959).

14 For example, publication in Great Britian, or public use in Great Britain, prior to the filing date is a bar to patent in Great Britain. Patents Act of 1949, 12, 13 \& 14 Geo. 6, c. $87, \S 32$. In West Germany, publication anywhere or public use in West Germany prior to the filing date or the "convention date" bars a patent, except when derived directly from the the applicant and less than six months before the application filing date. Germany, 53 PAT. \& Trade MARK Rev. 151 (1955).

${ }^{15}$ In any patent system with a "grace period" some way must be provided to resolve the case where a patent application is filed within the "grace period" but after some item of prior art. If, for example, a printed publication of an invention occurs prior to the patent application filing date, the question arises of whether the patent is justified. If the patent applicant in this case did not make the invention until after the printed publication, there is little justification for granting him a patent, for he is neither the first inventor nor the first person to make the invention publicly available. One way to resolve this problem is to concentrate on making the invention publicly available. In this case the system becomes a first-to-file system. Another way to resolve this problem is to use first inventorship as the criterion in those instances where the patent application is filed within the "grace period." This is the system now used in the United States.

10 For example, under the United States law a public use may exist even though the invention is used in a way that does not communicate the subject matter to the public. See Egbert v. Lippmann, 104 U.S. 333 (1881). Also, secret use of an invention for profit for more than the grace period is a patent invalidating abandonment of the invention under the United States law. Metallizing Eng. Co. v. Kenyon Bearing \& Auto Parts Co., 153 F.2d 516 (2d Cir.), cert. denied, 328 U.S. 840 (1946); MacbethEvans Glass Co. v. General Elec. Co., 246 F. 695 (6th Cir. 1917), cert. denied, 246 U.S. 659 (1918). 
ments of detailed patent disclosure and demonstrated utility far more stringent than those of most foreign countries-a fact that accounts for the relatively comprehensive United States patent documents as compared to the rather sketchy documents used in foreign countries. ${ }^{17}$ There is room to debate whether the United States system in this respect is the best course. Nevertheless, so long as the stringent requirements of the United States practice are enforced, collecting the data required for a United States patent application, and preparing the application, will require considerable time. Correspondingly there is a great prospect of a public use, publication, or other item of prior art possibly resulting from the inventor's own efforts. If patent applicants are to be subjected to such strict application requirements, there is a strong case in favor of the "grace period." The "grace period" in turn is made practically possible by the firstto-invent principle.

Additional considerations, which weigh in favor of first-to-file, are the problem of Patent Office interference proceedings, as well as the less often mentioned problem of determining priority of invention in litigation. It is not difficult to identify instances where the Patent Office interference practice has led to very unfortunate results. The classic examples are those of patents which have issued many years late, yet with the 17-year statutory life, because of delays occasioned by interferences. ${ }^{18}$ When attention is directed to these, as well as to

${ }^{17}$ The most dramatic example of the stringent standards applied under the United States patent law is that of "utility" in chemical patent application matters. In most countries a patent can be obtained with a mere statement that a chemical process has some utility. This expression may be very vague, such as a utility in the preparation of some chemical compound having "interesting properties." The United States law, as applied by the Patent Office with court support, requires that there be an explicit and specific statement as to the utility of a chemical process. In the recent case of Brenner v. Manson, 383 U.S. 519 (1966), the Supreme Court reversed the Court of Customs and Patent Appeals and upheld the Patent Office holding that a process for making a new chemical compound is not patentable unless some use of the chemical compound is set forth in the application and shown to be in existence. The Court rejected the argument that the new chemical compound (a close chemical relative of a large number of biologically active steroids) had utility for research purposes. For other decisions in this important field, see Petrocarbon Ltd. v. Watson, 247 F.2d 800 (D.C. Cir. 1957), cert. denied, 355 U.S. 955 (1958); In re Joly, I53 U.S.P.Q. 45, 243 (C.C.P.A. 1967) (especially dissenting opinions of Rich and Smith, JJ., narrowing the Manson ruling); In re Krimmel, 292 F.2d 948 (C.C.P.A. 1961); In re Nelson, 280 F.2d 172 (C.C.P.A. 1960); In re Bremmer, 182 F.2d 216 (C.C.P.A. 1950). See generally Note, 35 GEO. WASH. L. REV. 809 (1967).

${ }^{28}$ The classic instance of prolonged delay as a consequence of interference proceedings occurred with patent 2,705,484. See Hearings on S. Res. 92 Before the Subcomm. on Patents, Trademarks, and Copyrights of the Senate Comm. on the Judiciary, 84th Cong., 1st Sess. 287 (1955). 
lesser but still troublesome interference aberrations, it is easy to conclude that the interference practice ought to be abolished. This is what the President's Commission concluded, ${ }^{10}$ as well as the Royal Commission in Canada. ${ }^{20}$ The case in favor of this conclusion is lessened, however, by the fact that only a small number of patent applications become involved in interferences (an even smaller number of applications are involved in interferences that go to testimony), ${ }^{21}$ and by the general observation that reformation of the interference practice, rather than its abolition, may resolve the problem.

The third consideration, again pointing to first-to-file, is the matter of international conformity. At the present time, all of the examining patent offices are swamped with patent applications. There is every prospect that the situation will become worse before it gets better. Probably half or more of the total number of applications duplicate each other to some extent. ${ }^{22}$ As to these applications, similar (but not the same) examination is made in two or more countries. Thus, a duplication of patent office work results. The argument can and is being made that the ultimate solution to this problem should be an international patent system, involving one examination and one issuance. ${ }^{23}$ Nationalistic considerations, as

\footnotetext{
${ }^{10}$ President's Commission on the Patent System, supta note 1 , at 5-6.

20 Canadian Royal Commission on Patents, Copyright, and Industrial destgns, PATENTS OF INVENTION 23-4 (1960).

${ }^{21}$ Comprehensive intereference statistics appear in De Simone, Gambrell \& Gareau, Characteristics of Interference Practice, 45 J. PAT. OFF. Soc'y 503 (1963). The statistics are based on a $10 \%$ random sample of the 6,572 interferences declared in 1950 through 1959. The statistics show that the average number of interferences declared is about $0.9 \%$ of all patent applications. Id. at 516 . About $87 \%$ of the interferences involve two parties, about $11 \%$ involve three parties, and the balance have four or more parties. Id. at 544. These data together indicate that about $2 \%$ of all patent applications and patents become involved in interferences. Of the interferences that went through testimony and a final judgment on priority, about $45 \%$ terminated in favor of the "junior" party, that is, the second party to file. Id. at 521 . About $20 \%$ of the sample interferences actually went to testimony and a final hearing on priority. Id. at $\mathbf{5 2 2}$.

${ }^{22}$ Detailed statistics on the filing of patent applications throughout the world are given in Historical Patent Statistics 1791-1961, 46 J. PAT. OFF. SOc'y 89 (1964). The total of all patent applications filed by non-nationals in the various countries is often comparable to, and many times exceeds, the total of all patent applications filed by nationals of the respective countries. Id. at 135-i 1 . This indicates that at least half of the patent examinations entail duplication. It is likely that the extent of the duplication is even greater than the statistics suggest, because when a foreign application is filed it is frequently filed in a plurality of countries, resulting in just that much more duplication.

${ }^{23}$ On May 31, 1967, the United International Bureaux for the Protection of Intellectual Property (BIRPI) released a draft of a proposed Patent Cooperation Treaty designed to provide a greater degree of cooperation in the search activities of the
} 
well as economic and other differences between nations, make this a theoretical and not a presently attainable goal. There is, nevertheless, much to be gained by conforming the patent systems to a single arrangement so far as possible. Since first-to-invent is a distinctly United States patent system feature, it is a short step to conclude that conversion to first-to-file ought to be made in the interest of advancing international patent conformity. While there seems to be no doubt that a potential gain exists in this connection, the extent of actual benefit is debatable. ${ }^{24}$

A comparative evaluation of first-to-invent and first-to-file systems such as the foregoing, based primarily on analytical considerations, overlooks an important aspect of the choice in question-the extent to which the present United States patent system is really a first-to-file system. Actually, the present system provides a strong but rebuttable presumption that an invention is made on the date the patent application is filed. Numerous obstacles exist to proving an earlier invention date. To present this phase of the law in its true dimensions requires that the history of the United States first-to-invent system be traced, and that the various qualifications on first-to-invent also be examined. The balance of this paper is devoted to a treatment of these subjects. It is not the purpose of this paper to argue either for

various patent offices. 839 Official Gazetre of the U.S. PAT. OFF. 413 (1967). In addition, the United States Patent Office and the West Germany Patent Office recently completed an experimental exchange of patent search information. 838 OfFiciat GAzETTE of the U.S. PAT. OFF. 1225 (1967). This exchange resulted in about $60 \%$ of the prior art references supplied by each office to the other actually being used. Id. at 1226. The experiment involved 1,000 United States applications which were based on an identified prior German application and 1,000 German applications based on an identified United States application. Officials of the U.S. Patent Office concluded that the average quality of examination results, as well as search efficiacy, was considerably improved in these test applications. Id.

24 Neither the United States-German exchange experiment, nor the BIRPI proposal (see note 23 supra) requires the use of a first-to-file system in the United States. However, the extent of the benefits of international cooperation depend in some measure on the degree to which the respective patent systems are the same. There are a number of very important differences between the patent laws of the different countries, however, that have nothing to do with first-to-file or first-to-invent systems. For example, almost every country distinguishes between public use of an invention within its territory and public use elsewhere. Patentable subject matter varies from country to country, with some countries having designated classes of subject matter where no patents are permitted (e.g., pharmaceuticals, contraceptives, etc.) and others having judicially created exclusions from patentability (e.g., Brenner v. Manson, 383 U.S. 519 (1966), discussed in note 17 supra). For these and other reasons, the first-to-file vs. first-to-invent choice is only one of a number of points of departure between the respective patent systems. 
or against the first-to-file system. It may be observed, nevertheless, that the law here discussed necessarily lessens the force of the contention that a first-to-file patent system has great advantages for the United States, but also lessens the case to be made agianst a first-to-file approach.

\section{The Historical Development of First-to-Invent As the United States Patent System}

In 1623, after resurgence of the Tudor monopolies under James I, Parliament passed the Statute of Monopolies. ${ }^{25}$ This law was a limitation on the power of the sovereign to issue monopolies, including letters patent for inventions. The first section of the statute stated the general rule that all monopolies are void. Among a large number of exceptions to the general principle were two provisions directed, respectively, to existing patents granted by Parliament and to future patents for new inventions. Monopolies for new inventions were authorized if to "the true and first inventor."28

The framers of the Statute of Monopolies probably intended only to end the unhappy grant of Crown monopolies to existing products and methods of manufacture-the cases where no technical contribution that could possibly support a grant was involved. The statute reflects the statement of the Court of King's Bench in The Clothworkers of Ipswich.27 The court there held invalid a monopoly grant to the clothworkers guild, but noted that "if a man hath brought in a new invention and a new trade within the kingdom ... or if a man hath made a new discovery of any thing, in such cases the King . . . in recompence of his costs and travail, may grant by charter unto him [a patent] ..."28 Whatever the specific thoughts in the minds of those who framed the Statute of Monopolies, the expression "true and first inventor" has remained in the British patent law. While this language now has largely been merged into

$2521 \& 22$ Jas. 1 , c. 3 (1624).

so $I d$. \$6. "True and first inventor" was an expression intended to distinguish between monopoly grants for the manufacture, importation, and sale of salt, playing cards, and other well-known and existing products that the prior grants had covered, and patents for invention. For an account of the various monopoly grants by the Crown, see Price, The English Patents of Monopoly (1913). Appendixes B-G are lists of the various patents granted by about 1602. Most of these were to trades that existed at the time of the grants.

2778 Eng. Rep. 147 (K.B. 1615).

${ }^{28} \mathrm{Id}$. at 148 . 
the prior art requirement, it is the ancestor of the language of the United States law. ${ }^{28}$

The first United States patent act was passed in $1790 .^{30}$ This act differed importantly from the Statute of Monopolies. It provided for the grant of a patent to anyone complying with the Act, rather than authorizing a sovereign to grant patents as a matter of pleasure. It nevertheless borrowed from the Statute of Monopolies in suggesting that the patent could only go to the "first and true inventor or discoverer."31 Since this language was used in defining patent infringement suit defenses, the effect was to make first inventorship a condition of patentability. This act, and subsequent patent acts, ${ }^{32}$ led to consideration by the United States courts of what one must do to be the "first and true inventor or discoverer." The doctrine was early enunciated to the effect that the first inventor is the first person to "reduce to practice" the invention-that is, demonstrate its practical application. This principle was expressed in a classic Supreme Court opinion in 1891 as follows:

It is evident that the invention was not completed until the construction of the machine. A conception of the mind is not an invention until represented in some physical form, and unsuccessful experiments or projects, abandoned by the inventor, are equally destitute of that character. These propositions have been so often reiterated as to be elementary. ${ }^{33}$

${ }^{20}$ In Dollond's Case, Boulton v. Bull, 126 Eng. Rep. 651 (C.P. 1795), it was held that the patentee was the "true and first inventor" even though another had previously made the invention and had actually used it without making it public. Under British law, the defendant in an infringement suit can show that the invention "is not new having regard to what was known or used before the priority date of the claim in the United Kingdom." Patents Act of 1949, 12, 13 \& 14 Geo. 6, c. 87, $\S 32(1)$ (e). Thus, if the prior invention is made public-as required to make it patent-invalidating under Dollond's Case-it is also a part of the prior art under $\$ 32(\mathrm{l})$ (e), whether originating in a prior inventor or from the patentee himself. The question of whether there is a prior inventor thus becomes unimportant. Consideration of "true and first inventor" under the British law is accordingly now concerned with questions such as the status of one who has received a communication of the invention from abroad, employeremployee relations, and the like. See Terreld, PATENTs 23-26 (1965). Mr. Justice Story refused to follow Dollond's Case in Reed v. Cutter, 20 F. Cas. 435, 438 (No. 11,645) (C.C. Mass. 1841).

so Act of April 10, 1790, ch. 7, 1 Stat. 109.

sId. $\$ \S 5,6$.

32 The principal acts are: Act of Feb. 21, 1793, ch. 11, 1 Stat. 318; Act of July 4, 1836, ch. 357, 5 Stat. 117; Act of July 8, 1870, ch. 230, 16 Stat. 198; Patent Act, 35 U.S.C. $\$ \S 1-293$ (1964).

${ }^{33}$ Clark Threat Co. v. Willimantic Linen Co., 140 U.S. 481,489 (1891). Prior Supreme Court opinions expressing this thought include Seymour v. Osborne, 78 U.S. (11 Wall.) 516, 552 (1870), and Agawam Co. v. Jordan, 74 U.S. (7 Wall.) 583, 602 (1868). 
The 1790 Patent Act was superseded by the 1793 Act. ${ }^{34}$ The most important change of this act was abolition of the patent examination procedure and substitution of a registration system. However, a more enduring change was made with respect to the defense of prior inventorship, which was reworded to provide, as a defense to a patent infringement suit, that "... the thing, thus secured by patent, was not originally discovered by the patentee, but had been in use, $\ldots$ or that [the patentee] . . . had surreptitiously obtained a patent for the discovery of another person ...."35

The registration system was abandoned, however, and the Patent Office was established as an administrative agency, by the Patent Act of 1836.38 This act also made an important change in the "prior invention" defense of the 1793 Act. The language of the defense was altered to provide an infringement suit defense when the patentee ". . . surreptitiously or unjustly obtained the patent for that which was in fact invented or discovered by another, who was using reasonable diligence in adapting and perfecting the same ...."37 After the 1836 Act, the law remained essentially unchanged for over 100 years.

The net effect of these two statutory changes was to qualify-as to infringement suit defenses-the doctrine that the first inventor was the first to reduce to practice. In brief, if another "in fact invented or discovered" and was "using reasonable diligence," he was treated for infringement suit defense purposes as the first inventor. By its plain language, the 1836 statute referred to diligence "in adapting and perfecting" the invention, the equivalent to the reduction to practice. It followed that the Act provided for a case where another had done something less than reduce to practice and yet had "in fact invented or discovered." This was construed to mean conception of the invention. The reasonable diligence was construed to refer to the acts involved in reducing the invention to practice.

These statutes led to the rather complex rule that has endured to this day. In brief, under present United States patent law, the

The doctriue was first enunciated by Mr. Justice Story, while on circuit. See Washburn v. Gould, 29 F. Cas. 312 (No. 17,214) (C.C. Mass. 1844); Reed v. Cutter, 20 F. Cas. 435 (No. 11,645) (C.C. Mass. 1841); Bedford v. Hunt, 3 F. Cas. 37 (No. 1,217) (C.C. Mass. 1817); Woodcock v. Parker, 30 F. Cas. 491 (No. 17,971) (C.C. Mass. 1813).

st Act of Feb. 21, 1793, ch. 11, I Stat. 318.

ss Id. $\$ 6$.

as Act of July 4, 1836, ch. 357, 5 Stat. 117.

${ }^{37}$ Id. $\S 15$. 
rules for determining priority of invention for infringement suit defense purposes are as follows: ${ }^{38}$

1. One is not an inventor unless he has reduced the invention to practice.

2. The first of two persons to reduce the invention to practice is normally the first inventor.

3. In the exceptional situation where the second of two persons to reduce to practice can trace diligence towards such a reduction from a time prior to the conception of his rival, the second to reduce to practice (but necessarily the first to conceive the invention) is regarded as the first inventor.

This formula is relatively complex, but it has a virtue not to be ignored-it holds fast to the principle that the patent should be awarded for what the alleged inventor has done, not his haste in reaching the Patent Office. Thus, the activity of an inventor in working towards a reduction to practice is somewhat privileged activity that can be undertaken (if done diligently) without fear that an intervening rival will obtain the right to a patent.

While the above rules evolved from statutes directed to the defense of a patent infringement suit on the ground that another is the first inventor, they have been applied, since at least the latter part of the 19th Century, to the question of priority of invention as between rival patent applicants in Patent Office interference proceedings. Beginning in 1952, however, the patent statutes have set forth the reduction to practice, diligence, and conception criteria for both interference and patent validity purposes. ${ }^{30}$

${ }^{88}$ The development and effect of the rules relating to priority of invention is set forth in the analytical opinion of Judge Colt in Automatic Weighing Mach. Co. v. Pneumatic Scale Corp., 166 F. 288 (1st Cir. 1909). For a general discussion of the present law and practice see Crews, Introduction to Interference Law and Practice, 46 J. PAT. OFF. SOc'y 755 (1964).

s9 Section $102(\mathrm{~g})$ of the current Patent Act provides that: "A person shall be entitled to a patent unless-...

“ $(\mathrm{g})$ before the applicant's invention thereof the invention was made in this country by another who had not abandoned, suppressed or concealed it. In determining priority of invention there shall be considered not only the respective dates of conception and reduction to practice of the invention, but also the reasonable diligence of one who was first to conceive and last to reduce to practice, from a time prior to the conception by the other." 35 U.S.C. $\$ 102$ (g) (1964).

In addition $\$ 282$ (2) of the Act provides that "The following shall be defenses in any action involving the validity or infringement of a patent ...

"(2) Invalidity of the patent or any claim in suit on any ground specified in part II of this title as a condition for patentability . ..." 35 U.S.C. $\$ 282$ (2) (1964). 


\section{The Evolution of a Hybrid Patent System}

\section{IN The UnITEd States}

After the term "first inventor" had been equated with "first to reduce to practice," a new dilemma emerged. The Patent Acts of 1790,1793 , and 1836 were clear in requiring that the patentee be the first inventor. It was also clear, however, that the statutes did not expressly require acts other than the filing of the patent application to obtain a patent. This problem reached the courts at least by 1872 in Wheeler $v$. Clipper Mower and Reaper Company. ${ }^{40}$ It was there argued in defense of a suit that the patentee had not reduced the invention to practice before filing the patent. The court held that the patent was valid and the proposition "wholly unsound." It reasoned that the statute did not impose the condition of a reduction to practice and that the Commissioner and the courts could not require proofs of a reduction to practice which were not required by the statute.

It remained for the Telephone Cases ${ }^{41}$ to establish, beyond question, the rule that the patent applicant need not reduce to practice. That case concerned Bell patent 174,465 for the so-called harmonic telegraph. This patent included, as Figure 7, a diagrammatic showing of a telephone system, coupled with a rather short description stating that the apparatus of Figure 7 would transmit vocal or other sounds. All of this was sheer theory at the time. The apparatus had not been constructed. No experiments that would directly lead to any conclusion as to its workability had been made. It was not until the actual litigation that the particular apparatus shown in the patent was constructed. Happily for Bell, it then worked. The patent was invalid, the opponents argued, because Bell had not constructed a workable apparatus prior to the patent. The Supreme Court held that the Bell patent was valid, whether or not Bell had in fact actually reduced the invention to practice at the time of filing the application. In the words of the Court:

It is quite true that when Bell applied for this patent he had never actually transmitted telegraphically spoken words so that they could be distinctly heard and understood at the receiving end of his line, but in his specification he did describe accurately and with admirable clearness his process, that is to say, the exact electrical

1029 F. Cas. 881 (No. 17,493) (C.C.S.D.N.Y. 1872).

«2 Dolbear v. American Bell Telephone Co., 126 U.S. 1 (1888). 
condition that must be created to accomplish his purpose, and he also described, with sufficient precision to enable one of ordinary skill in such matters to make it, a form of apparatus which, if used in the way pointed out, would produce the required effect, receive the words, and carry them to and deliver them at the appointed place....

The law does not require that a discoverer or inventor, in order to get a patent for a process, must have succeeded in bringing his art to the highest degree of perfection. It is enough if he describes his method with sufficient clearness and precision to enable those skilled in the matter to understand what the process is, and if he points out some practicable way of putting it into operation. ${ }^{42}$

With a clear doctrine that one is not an inventor who has not reduced the invention to practice-and with equally clear authority that merely describing an invention is sufficient to support a patentit was a short step to resort to the equivalent of a common law fiction as applied to the patent law. Thus the doctrine of the "constructive reduction to practice" came into being. By the time of the Telephone Cases, and ever since, it has been settled that filing an allowable patent application is a constructive reduction to practice, and that such "constructive reduction to practice" is for all legal purposes equivalent to an actual reduction to practice.

A related legal development has taken place with respect to the status of a patent application as demonstrating prior inventorship for purposes of defense in an infringement suit. The early holdings that reduction to practice was required for an invention generally occurred when defendants sought to prove prior invention as a defense to an infringement suit. ${ }^{43}$ The Telephone Cases and subsequent cases settled the doctrine that filing a patent application is a constructive reduction to practice. The question then arose whether the fact of filing provided complete proof of invention as of the filing date for patent infringement defense purposes by a third party unrelated to such application. The matter was settled by the Milburn case, ${ }^{44}$ which held that the entire content of the disclosure of a patent is deemed to have been invented at least as of the date the patent application was filed.

\footnotetext{
a Id. at 535-36.

${ }^{43}$ E.g., Seymour v. Osborne, 78 U.S. (11 Wall.) 516 (1870); Agawam Co. v. Jordan, 74 U.S. (7 Wall.) 583 (1868).

“Alexander Milburn Co. v. Davis-Bournonville Co., 270 U.S. 890 (1926).
} 
The patent in the Milburn case was filed by one Whitford in March, 1911. However, in 1912 a patent was issued to one Clifford on a writing which described the invention claimed by Whitford. The Clifford application was filed in January, 1911. Clifford did not claim the subject matter asserted by Whitford. The defendant argued that the earlier filed Clifford application showed that someone had made the invention prior to January, 1911, that Whitford had not attempted to show his own date of invention prior to January, 1911, and that Whitford was thus not the first inventor. The plaintiff insisted that Clifford's failure to claim the invention was an abandonment, or at least an indication that Clifford was not the inventor. In a typically short opinion by $\mathrm{Mr}$. Justice Holmes, the Court sustained this contention. In brief, said the Court, "one really must be the first inventor in order to be entitled to a patent," 45 and "Clifford's disclosure made it impossible for Whitford to claim the invention at a later date." ${ }^{48}$

The Milburn rule is now section 102 (e) of the Patent Act. ${ }^{47}$ The rule has been expanded by judicial decision to treat the disclosure of a copending patent application for essentially all purposes like a printed publication-as prior art as to the date of invention..$^{48}$ This is in sharp conflict with the idea that the first-to-invent feature of the United States patent system centers on what is physically done in making the invention. Indeed, since the disclosure and not the claims of the patent application determine its effect as a reference under the Milburn rule, we have a patent application treated broadly as the equivalent of a reduction to practice. It may be argued that this is going too far with the doctrine of constructive reduction to practice. This seems to be precisely how the lower court viewed the matter in the Milburn decision.49 Despite such theorizing, however, it is settled law that the constructive reduction to practice doctrine

"s Id. at 400 .

's $I d$. at 401.

"7 Section 102 (e) of the Patent Act now provides that: "A person shall be entitled to a patent unless-...

"(e) the invention was described in a patent granted on application for patent by another filed in the United States before the invention thereof by the applicant for patent ...." 35 U.S.C. $\$ 102$ (e) (1964).

18 See Hazeltine Research, Inc. v. Brenner, 382 U.S. 252 (1965).

10 See Davis-Bournonville Co. v. Alexander Milburn Co., 297 F. 846 (S.D.N.Y.), aff'd, 1 F.2d 227 (2d Cir. 1924), rev'd, 270 U.S. 390 (1926). 
applies to any United States application on which a patent issues for all the subject matter it discloses, whether or not claimed.

The rule that a domestic patent application is a constructive reduction to practice for all that it discloses is of cardinal importance. Under this rule, by the single act of filing a patent application, the inventor obtains the full benefit of the filing date as his date of invention.00 No other proofs are required to put him in the same position as if he actually reduced the invention to practice on that date. There are a variety of practical situations in which an early filing date is of great advantage. For example, the combination of an early filing date and an early conception date may, in relation to a rival inventor, demonstrate prior invention on the basis of the combination of first conception and first reduction to practice. Another common case occurs when the patent application filing date -though after the reduction to practice of a rival-is sufficiently early to enable a showing of diligence running back from the filing date to the conception date of the rival inventor.

The benefits of an early filing date are further enhanced by the stringent standards of proof necessary to show invention prior to the application filing date in interference proceedings or infringement litigation. Conception, diligence, and actual reduction to practice are not easy to prove. The date of conception is the date when there is "the complete performance of the mental part of the inventive act [and].... all that remains to be accomplished in order to perfect the act or instrument belongs to the department of construction, not invention."51 It requires "the formation in the mind of the inventor, of $a$ definite and permanent idea of the complete and operative invention, as it is thereafter to be applied in practice, that constitutes an available conception, within the meaning of the patent law." Diligence can be shown only when the inventor has concentrated attention on the reduction to practice to the substantial exclusion of work on other conceptions. ${ }^{53}$ An actual reduction to practice requires not only a construction of an operable device, or performance of the process, but also sufficient testing to satisfy a competent worker

\footnotetext{
${ }^{50}$ See, e.g., Automatic Weighing Mach. Co. v. Pneumatic Scale Corp., 166 F. 288, 298 (1st Cir. 1909).

6x Mergenthaler v. Scudder, 11 App. D.C. 264, 276 (1897).

62 Id. (italics in original).

ts Fageol v. Midboe, 56 F.2d 867 (C.C.P.A. 1932).
} 
in the field that the invention is ready for production. ${ }^{54}$ In addition to these substantive requirements, the party seeking to prove a date of invention prior to an application date must corroborate the testimony of the alleged inventor at all significant points. The procedural requirement here is severe. As observed in one leading decision:

All of the witnesses appear to be men of high character, and the testimony of appellant, together with his notebook and time cards, is very persuasive; but unless there be independent corroboration of his testimony respecting actual reduction to practice, no award of priority based upon such actual reduction may be made. ${ }^{55}$

These obstacles to proving a date of invention prior to patent application filing date are of great practical importance. They account for the record that most interferences are resolved in favor of the party first to file, and for the general experience that the infringement suit defense of prior invention, when successful, is usually supported by documents or other strong proofs. ${ }^{56}$ In short, although the law is clear that the defendant in an infringement suit, or a party to an interference, can show invention prior to the patent application filing date, the practical burden is quite heavy, making the benefit of an early filing date very great indeed.

\section{Strict First-to-File Provisions of United States Patent Law}

Finally, we turn to a class of inventions where the United States is now using a strict first-to-file system-inventions made in a foreign country. The patent laws have contained a variety of provisions respecting the issuance of patents to citizens only, to resident aliens, and later to all persons ${ }_{n}^{57}$ The defense of prior invention has likewise

\footnotetext{
st Payne v. Hurley, 71 F.2d 208 (C.C.P.A. 1934).

88 Kear v. Roder, 115 F.2d 810, 817 (C.C.P.A. 1940).

so See De Simone, Gambrell \& Gareau, supra note 21, at 517-91. For an illustration of the detail required for a successful defense of prior inventorship see Corona Cord Tire Co. v. Dovan Chemical Corp., 276 U.S. 358 (1928).

${ }^{87}$ Act of April 10, 1790, ch. 7, § 1, I Stat. 109 (any person); Act of Feb. 21, 1793, ch. 11, § I, 1 Stat. 318 (citizens only); Act of April 17, 1800, ch. 25, § 1, 2 Stat. 37 (certain resident aliens); Act of July 13, 1832, ch. 203, 4 Stat. 577 (resident aliens who have declared intent to become citizens); Act of July 4, 1836, ch. 357, $\$ 9,5$ Stat. 117 (any person, but with a fee discrimination against non-resident aliens, especially subjects of Great Britain); Act of March 2, 1861, ch. 88, § 10, 12 Stat. 246 (any person, and fee discrimination against aliens abolished as to all countries not discriminating against the United States); Act of July 8, 1870, ch. 230, §24, 16 Stat. 198 (any person, with no difference in fees for aliens under any circumstance).
} 
been varyingly expressed in the statutes, but without reference to invention in a foreign country. ${ }^{58}$ However, in stating the requirements for obtaining a patent, the 1870 Act required that the invention be not "known or used in this country before the invention thereof" by the patentee.59 Also, in 1903 the law was changed to provide that under certain circumstances a United States application should have the same effective filing date as an earlier-filed foreign patent application. ${ }^{60}$ The statutes in this form were construed in Electric Storage Battery Company v. Schimadzu. ${ }^{61}$ The Court there held that a foreign inventor was not precluded from showing his own foreign acts of invention prior to the effective patent application date, even though this was somewhat inconsistent with the infringement defense as to prior invention in foreign countries. However, Congress abolished the rule of the Schimadzu case in 1946,62 and section 104 of the Patent Act now provides that:

In proceedings in the Patent Office and in the courts, an applicant for a patent, or a patentee, may not establish a date of invention by reference to knowledge or use thereof, or other activity with respect thereto, in a foreign country .... ${ }^{64}$

This rule is usually regarded as one of rather exceptional applicability and not an alteration of the main thrust of the United States patent law. But when we recall that 22,326 applications were filed from foreign countries in 1965, and that this is approximately 25 per cent of the total number of applications, the figures can

${ }^{88}$ Act of April 10, 1790, ch. 7, §5, 1 Stat. 109: "[I]f it shall appear that the patentee was not the first and true inventor or discoverer"; Act of Feb. 21, 1793, ch. 11, §6, 1 Stat. 318: "the thing thus secured by patent was not originally discovered by the patentee, but had been in use, or had been described in some public work anterior to the supposed discovery of the patentee, or that he had surreptitiously obtained a patent for the discovery of another person"; Act of July 4, 1836, ch. 357, § 15, 5 Stat. 117: "the patentee was not the original and first inventor or discoverer of the thing patented, or of a sub. stantial and material part thereof claimed as new, or that it had been described in some public work anterior to the supposed discovery thereof by the patentee, or had been in public use, or on sale, with the consent and allowance of the patentee before his application for a patent, or that he had surreptitiously or unjustly obtained the patent for that which was in fact invented or discovered by another, who was using reasonable diligence in adapting and perfecting the same."

to Act of July 8, 1870, ch. 230, §24, 16 Stat. 198 (emphasis added). The prior law, set forth in the Act of July 4, 1826, ch. $357, \S 6,5$ Stat. 117, omitted the qualification "in this country."

${ }^{\circ 0}$ Act of March 3, 1903, ch. 1019, § 1, 32 Stat. 1225.

${ }^{61} 307$ U.S. 5 (1939).

62 Act of Aug. 8, 1946, ch. 910, §9, 60 Stat. 940.

os 35 U.S.C. § 104 (1964). 
hardly be dismissed as trivial. ${ }^{84}$ Thus, a very real segment of the United States patent system is operating under section 104.

The striking thing about section 104 is that it provides a pure first-to-file system. The inventor in a foreign country can gain no benefit from an actual reduction to practice, or any other of the acts that would go to making an invention date if they were done within the United States. His only recourse is to file a patent applicationeither abroad under the International Convention followed by a timely United States application, or directly by a United States application. ${ }^{65}$

\section{Conclusion}

The above analysis does not exhaust the possible points of discussion on the extent the United States patent law reflects first-to-file considerations. The illustrations and history discussed do, however, show that the system cannot be accurately classified as either a firstto-file or first-to-invent system. Rather, it is a dual system, using first-to-file principles in some respects and first-to-invent principles in other respects.

It can be argued that this conclusion supports those who would change the United States patent system to a first-to-file system. At least, existing experience with this hybrid approach, together with the experience of nearly all foreign countries, shows that a first-to-file patent system is a workable alternative.

But the further conclusion that a first-to-file system would be better for the United States should not be too hastily drawn. Even though our present system contains many first-to-file features and gives a very great advantage to a person who files first, it retains at least three important first-to-invent aspects. First, in appropriate cases it is possible to prove a pre-filing date of invention and thereby secure a valid patent notwithstanding the earlier-filed application of another. This means that a domestic inventor can often take the time required to perfect the invention before filing. Second, the system provides a grace period as to the prior art. This period is generally considered desirable and, in any event, makes practical the stringent

\footnotetext{
os PAT. Office ANN. REP. 26 (1966). The total number of patent applications filed during fiscal 1965 was 89,234 . Id. at 15 .

os For discussion of the International Convention see E. Penrose, The Economics of the INTERnationaI PATENT System 42 (1951).
} 
disclosure requirements unique to the United States patent system. Thirdly, patent issuance on the basis of first-to-invent is entirely consistent with the defense that the patentee was not the true and first inventor. It seems plainly inequitable to permit a second inventor to stop an earlier inventor from using his own prior invention-a result that can occur under a first-to-file system. Our hybrid system avoids this result, and yet provides many of the features of a firstto-file patent system.

The 1967 patent law debate will continue. But the real issue ought not be whether a strict first-to-invent system is better than a first-to-file system. Rather, the issue should be whether our highly qualified first-to-invent system makes possible benefits that outweigh the desirable attributes of a pure first-to-file patent system. 